\title{
THE STUDY OF FIGURATIVE LANGUAGES USING STYLISTICS THEORY IN WHAT MY MOTHER DOESN'T KNOW BY SONYA SONES
}

\author{
Winnie $^{1}$; Akun ${ }^{2}$ \\ 1,2English Department, Faculty of Language and Culture, Bina Nusantara University, \\ Jl Kemanggisan Ilir III, No. 45, Kemanggisan/Palmerah, Jakarta Barat 11480 \\ ho_win_nie@yahoo.com, akun@binus.edu
}

\begin{abstract}
What My Mother Doesn't Know is a novel-in-verse by Sonya Sones which tells about a teenage girl named Sophie who tries to find her Mr. Right and her bad relationship with her parents. In the end, Sophie finds her Mr. Right who is actually not her type of boy friend but he can make her feel happy and even though she hates her parents, she realizes that she loves them nevertheless. The purpose of this article is to prove that the author's use of style can reveal the themes of novel-in-verse The analysis of the novel-in-verse focuses mainly on the themes and the figurative language of simile, metaphor, personification, paradox, and hyperbole. Research methods are conducted in qualitative method in the form of library research and statistics to calculate how many poems use the five figurative languages and are related to the themes. In the analysis, the author's style is figurative language and there are three themes that can be taken from the novel-in-verse. The themes are overwhelmed feeling does not show the true feeling, the bond of family will always be there, no matter how hateful we are to them and love is not determined by someone's physical appearance. The result shows that 91.36 percents of poems that use the five figurative languages are related to the themes. It can be concluded that the author's style in writing the novel-in-verse can reveal the three themes.
\end{abstract}

Keywords: novel-in-verse, stylistics, figurative language

\begin{abstract}
ABSTRAK
What My Mother Doesn't Know adalah sebuah novel berbentuk puisi karangan Sonya Sones. Mengisahkan pencarian jati diri Sophie, gadis belia yang mencari pria idaman (Mr.Right) dan hubungan yang kurang baik dengan kedua orang tuanya. Meski sampai akhir cerita ia tak pernah menemukan pria idaman (Mr. Right), Sophie justru bertemu pria yang jauh dari bayangannya, namun Ia bahagia hidup dengannya. Satu lagi, akhirnya Sophie menyadari peran penting orang tua bagi hidupnya. Tujuan artikel untuk mengetahui apakah gaya penulisan novel yang puitik mampu menyampaikan pesan pada pembaca. Artikel memfokuskan bahasan pada tema, metafora, personifikasi, paradok, dan hiperbola yang dibahas menggunakan metode kualitatif dengan mencari berapa banyak puisi yang mengandung kalimat figuratif yang sesuai tema.. Hasilnya, 91.36 persen membuktikan bahwa gaya penulisan ini mampu menyampaikan pesan kepada pembaca.
\end{abstract}

Kata kunci: novel puitik, stilistika, kalimat figuratif 


\section{INTRODUCTION}

This Article consists of the analysis of one of Sonya Sones' novel-in-verses entitled What My Mother Doesn't Know that uses Stylistics Literary Criticism. Novel-in-verse, or usually called as free verse novel, has the same form as poetry. However, the stress pattern and line lengths in a poetry are decreased in novel-in-verse and so does the rhyme (Talib, 2007). In Literary studies, the goal of Stylistics study in literature is to show how the technical linguistics featured of a literary work, such as the grammatical structure of its sentences, contributes to its overall meanings and effects (Barry, 1995, p. 202). Besides that, Stylistics can show its excellence and enables a thorough analysis of literary works, ranging from poetry, short story, song lyrics, novels, etc.

Sonya Sones' novel-in-verse is an interesting object to analyze because it is made in a free verse form and it is a simple love story of a teenage life. However, the chosen vocabulary and its words arrangement make this novel-in-verse cannot be easily understood. Therefore, it is interesting to find the essence of the poetry and to analyze this poetry using Stylistics approach to find what the author's intention is in the novel-in-verse.

Sophie is a beautiful teenage girl who is already dating out for several times. She has her own standard in picking an ideal boyfriend. He has to be cool and handsome. However, there is one boy named Murphy who is out of Sophie's standard, but he secretly admires Sophie. Sophie always thinks negatively about Murphy, and she tries to avoid him and find her charming prince. Sophie's first boyfriend is Lou. They break up at second grade of junior high school because Lou loves another girl. However two weeks after that, Sophie finds another new boyfriend named Dylan. They have so many sweet memories but Sophie is aware that he is not her Mr. Right. After breaking up with Dylan, Sophie meets Chaz in chatting room, however Chaz is also not the right person for Sophie.

In a Halloween dance party, Sophie feels that she has found her charming prince on the dance, even though she cannot see the face behind the mask. Sophie imagines the face behind the mask must be very handsome, because his attitude is very kind and gentle, just like a prince, but she became surprised when she knows that it is Murphy that she fells for. In the end, Sophie realizes that love does not depend on the looks, but on the heart, and she finally can accept Murphy, whose real name is Robin, as her boyfriend.

Sonya Sones was born in Boston and was an overprotected child living in the nearby suburb of Newton, but now she is living in Hollywood. Since she loved reading to both her children, she then tried to make children stories. She entered a poetry class at UCLA, under the teaching of Myra Cohn Livingston. So far, she has written four novels-in-verse (Sones, 2008). Sonya's novel-in-verse, What My Mother Doesn't Know, was the winner of Entertainment Weekly, winner of the Iowa Teen Book Award (2005 - 2006), named by the American Library Association as one of the Top Ten Most Challenged Books of 2004 and 2005, named a booklist Editor's choice (2001), and has won many other awards. So far, this novel-in-verse has been published in the United States, France, Germany, Korea, Indonesia and the United Kingdom (Sones, 2008).

The problems to be discussed in this article are to try to discuss the dominant themes in the novel-in-verse; to point out the closest meaning of the simile, metaphor, personification, paradox, and hyperbole; to analyze the five figurative languages to reveal three themes in the novel-in-verse; and to analyze the relationship between the special uses of the five figurative languages and the themes. It is used as a purpose to make the readers understand more about figurative language of simile, metaphor, personification, paradox, and hyperbole and stylistics theory. 
The scope in this analysis is a novel-in-verse by Sonya Sones entitled What My Mother Doesn't Know, is focusing on the three themes that have been decided and the lines which contain the figurative language of simile, metaphor, personification, paradox, and hyperbole.

The first step of analysis begins by reading the whole novel-in-verse several times. Before entering the analysis, the themes are decided, and after that, the figurative language of simile, metaphor, personification, paradox, and hyperbole are listed. Then, the closest meaning of each figurative language is decided. In analyzing the figurative languages and the process of stylistics analysis, the lines taken are the ones related to the themes. The last step is to find out the relationship between the five figurative languages and the themes.

This novel-in-verse is very interesting to analyze because Sonya writes the story in form of verse to describe Sophie's story. The author of the novel uses mostly figurative language so to understand the essence of the story we need to fully understand about free verse, and the theory of figurative language and stylistics, first.

\section{DISCUSSION}

\section{Free Verse}

French poets such as J.Laforgue, A.Rimbaud, S.Mallarme, and P.Verlaine, invented "vers libre" or free verse in the end of 19 century. The Oxford Companion to the English Language stated further that free verse gives modern poets more flexibility in pointing out their statement as the replacement of meter sense an ideas are used to divide lines (McArthur, 1995, pp. 416). The meaning of free in free verse only means that it is free from the regular convention of METRES often seen in traditional verse (Wales, 2001: 93).

In Literature: An Introduction to Fiction, Poetry, and Drama (1979: 529), Kennedy explained that free verse is also can be called as open form verse. The main goal is to find a new and individual arrangement for words in every poem. The poem has no rhyme or meter that applies to a whole poem. Long story in verse or prose was famous in the middle ages such as knights and adventures that is called romance because it is written in romance language such as French and Latin (Kennedy, 1979: 232). Free verse is lines differing only as syntactical point but does not have anything to do with the meaning relating to the metrical pattern (Bradford, 1997: 21).

Richard Bradford said in his book, Stylistics (1997:21) that there are three basic categories in free verse. First, when a poem still followed the rules of traditional poetry but the elements are extended to fit the new style. Second, when a poem's form or structure shows "spontaneity of ordinary speech" without regards to the meter like in old poem. Third, when a poem bends all the rules of syntax and meter.

\section{Theme}

Thomas R. Arp and Johnson (1959:130) explained Theme to control the idea of a story. In determining theme in a story, we need to ask what is the purpose of the story and what view of life it supports. However, not all stories have theme. In commercial fiction, plot and suspense are more important than theme. 
Principles in making theme are (Arp \& Johnson, 1959: 134).

1. Theme should be expressible in the form of a statement with a subject and a predicate.

2. Theme must be stated as generalization larger than is justified by the terms of the story.

3. The author must be careful not to make the generalization larger than is justified by the terms of the story.

4. Theme is the central and unifying concept of a story.

5. There is no one way of stating the theme of a story.

6. Theme must also avoid of being too repetitious of common sayings. Such as "You can't judge a book by its cover" or "A stitch in time saves nine".

\section{Stylistics}

According to Peter Barry (1995: 202) Stylistics is the way of making a criticism on literary texts by linguistics elements. In literature, Stylistics can provide a thorough analysis since it has a lot of tool and can cover a lot of areas. The Stylistics approach deals mainly with the textual analysis and its technical usage in a literary text.

In A Dictionary of Stylistics (2001: 437), Wales explained that Stylistics is the study of style. It is variable in terms of the approach that exists since it is deeply affected by the vastness in linguistics and literary criticism. The purpose of stylistics criticism is to identify the style in the formal text and its important meaning in the text.

There are 4 categories of Stylistics in Literature: Lexical Categories, Grammatical Categories, Figurative Language, and Context and Cohesion. , Lexical stylistics deals with the style that concerns about word choice. The analysis of lexical stylistics can be seen from the author's choice if vocabularies such as simple / complex words, general term / technical term, words associations with other emotions or idioms, or the choice of word class (noun, verb, adverb and adjective) (Leech \& Short, 1981: 75).

The second is Grammatical Stylistics. The analysis of grammatical stylistics can be determined by looking for the composition of the sentence such as the use of simple or complex sentence, the clause use, the phrases uses and other structure related elements (Leech \& Short, 1981: 76).

In Figurative Language Stylistics, the author's style can be seen from the use of figurative language in the literary work. The analysis of figurative language stylistics may cover the choice of the figurative language, the meaning of figurative language, and the specific meaning or purpose of using the figurative language as employed by the author. In other words: why the author chooses to use that specific figurative language and does the figurative language contain the author's own interpretation of the world (Leech \& Short, 1981: 78).

The use of cohesion in Stylistics is the easiest to determine because the ideas of the story from the beginning until the end should never change. It is achieved by the way one part of the text is linked to another. Meanwhile, context deals with the relation of the text with the social discourse in the real word (Leech \& Short, 1981:79).

\section{Figurative Language}

This article focuses in Figurative Language Stylistics. Figurative language uses unusual feature semantically or grammatically. Meanwhile, Figures of speech are used in creating imagination by comparing two or more different things (Wales, 2001: 176). In A Dictionary of Stylistic, Plett (1977) stated that figure is the smallest deviant language unit and figures do not follow the rules of linguistic (Wales, 2001:176). 
This article concentrates on five dominant figurative languages: simile, metaphor, personification, paradox, and hyperbole. Simile is a figurative language used when we want to explain the resemblance of two objects (in shape, color, characteristics, etc) indirectly using connectors, such as like, as, than, similar to, resembles, or seems. Meanwhile, Metaphor is a figurative language used when we want to make direct comparison between two objects. Metaphors may take one of four forms, depending on whether the literal and figurative terms are respectively named or implied (Arp, 1984: 62).

Personification is a figure of speech when any inhuman objects are given human qualities and attributes to achieve dramatic effects (Kennedy, 1979: 495). Paradox is a statement that apparently self-contradictory but on closer inspection reveals a truth normally hidden (Kennedy, 1979: 497). And last but not least, Overstatement or hyperbole is an outrageous exaggeration of an object's attribute used to magnify a fact or emotion to make an emphasis of its importance. It is the same like all figures of speech. It is made by various effect such as humor or grave, fanciful or restrained, convincing or unconvincing (Arp, 1984: 102). These five figurative languages are found inside the novel-in-verse, and help contributing meanings to the themes of the story, as will be explained in the research report.

\section{Themes in the novel-in-verse}

There are three main themes in the novel-in-verse, which are:

1. Overwhelmed feeling does not show the true feeling.

The exaggeration feelings are the happy expression that Sophie feels when she is in love with Dylan. These expressions are compliment expression, attractiveness, and Sophie's happy expression with Dylan. The expressions are not true feeling but it is just a moment of happy expression, because at that time Sophie likes Dylan not because of love but because Sophie likes Dylan's physical appearance. This can be proven through one sentence in simile seems like hours even though it's probably only been twenty minutes (Double Date: 344). It means that this sentence proves that Sophie starts to feel bored with Dylan and does not really like to spend days with Dylan. Even though Dylan has good physical appearance that attracted Sophie, this cannot last long because to love somebody is not only just looking at the physical appearance but also how they can attract us emotionally.

2. The bond of family will always be there, no matter how hateful we are to them.

This theme is related to Sophie and her parents' relationship. Actually, Sophie loves her parents but she hates their attitude toward Sophie when she was still a kid until she grew up now. Sophie thinks that for all this time her parents do not care with her and her life, but behind it all actually Sophie does not want to hate them. She loves them and hopes that at least they can be interested in her life. It can be inferred that no matter how hateful Sophie is to her parents still behind it all Sophie does not want to hate them and when her parents change, she will forgive them immediately.

3. Love is not determined by someone's physical appearance.

This theme is related to Sophie and Murphy because Murphy is not the type that Sophie used to like. When Sophie breaks up with Dylan, Sophie meets with a masked man at the Halloween dance party, she believes that the masked man must be a handsome guy because his attitude is very kind and polite. But unfortunately, Murphy is the masked man, and his real name is Robin. However, this does not make Sophie sad because she finally realizes that behind Murphy's boring appearance, he has a charisma that is not owned by other guys. Besides that, Murphy can make Sophie always smile and treats Sophie politely and kindly. This theme can give a good message for every body that we must not love someone because of physical attractiveness alone, but the behavior must be counted on also. 


\section{The stylistics analysis of the five figurative languages in the connection with the three themes}

After deciding the themes in the novel-in-verse, the lines of simile, metaphor, personification, paradox, and hyperbole will be analyzed using the theory of stylistics. The lines that will be analyzed are the lines related to the three themes mentioned. Afterwards, the lines using simile, metaphor, personification, paradox, and hyperbole will be listed. Besides the meaning, the poem title and pages in the table will also be added. The words in the lines will be analyzed using Oxford Advanced Learners English Dictionary.

\section{Simile}

There are 26 lines of Simile in the novel-in-verse that contributes to the three themes. This is one of the examples:

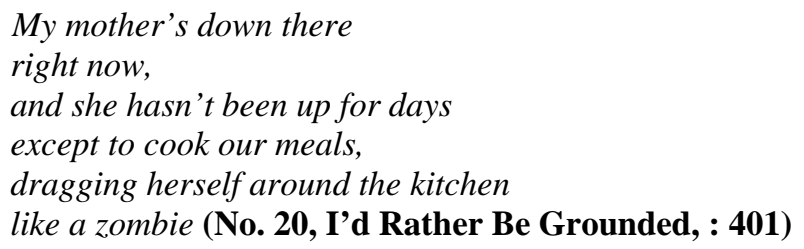

The main concern in these lines is the words mother and zombie. The author uses the word zombie as the noun with a purpose instead of using dead people. Zombie means a person who seems only partly alive, without any feeling or interest in what is happening. The author uses the word zombie to explain Sophie's mother who does not speak and laugh but she still can walk to do something. Therefore, if the author uses the word dead people, the meaning of the lines becomes different when describing her mother who does not speak and do anything; she just sleeps or sits down like dead people. Her mother acts like that because she is angry with Sophie. Sophie's mother is angry because Sophie's doesn't want to wear the gown that her mother bought for her.

The purpose of these lines is to show Sophie's anger, annoyance, and sadness because she does not like her mother's attitude that does not want to speak with her. These lines are related to the third theme because it shows annoyance and anger expression to her mother who scold her.

\section{Metaphor}

There are 43 lines of Metaphor in the novel-in-verse that contributes to the three themes. This is one of the examples:

And know how it feels

to be buried under an avalanche of guilt (No. 25, My Masked Man Would Know:403)

The main concern in these lines is the words buried, avalanche and guilt. Buried as a verb means to destroy, damage, injure or kill somebody / something by fire. Avalanche as a noun means a mass of snow, ice and rock that falls down the side of a mountain. Guilt as an adjective means feeling ashamed because you have done something that you know is wrong or have not done something that you should have done. The three words are used by the author to explain someone feeling who is really hurt because of guilty feeling. Sophie feels really sorry or guilty to her mother because she changes the gown for the Halloween dance party that was chosen by her mother.

These lines are related to the second theme because it explains about Sophie and her mother relationship which never get along because Sophie feels her mother never loves her. 


\section{Personification}

There are 24 lines of Personification in the novel-in-verse that contributes to the three themes. This is one of the examples:

whispering of our fingers (No. 4, Between Classes With Dylan: 265)

The main concern in the line is the words whispering and fingers. Whispering is a verb that means to speak very quietly to somebody so that other people cannot hear what you are saying. Meanwhile, Fingers is a noun that means one of the four long thin parts that stick out from the hand (or five, if the thumb is included). The line wants to explain that when Sophie and Dylan were in love, their fingers hold each other. The line here is used for the sake of romanticizing. The author uses the word's poetic quality to make the poem seem more emotional and emphasize the happiness of Sophie.

The line uses the figurative language Personification. Finger is the inhuman object and the human quality is whispering. After analyzing the line, we know that the line is related to the first theme. The line explains about Sophie's happiness and she expresses it in exaggerated words. The line shows an overwhelmed feeling that Sophie expresses to Dylan when she feels in love with Dylan.

\section{Paradox}

There are 7 lines of Paradox in the novel-in-verse that contributes to the three themes. This is one of the examples:

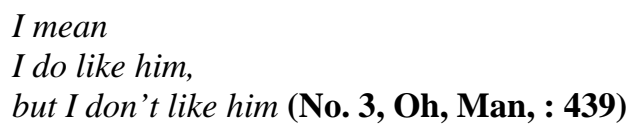

There are two contradictory words that are focused in the lines. There are like and don't like. The word like as a verb wants to show to the reader that Sophie has a feeling of like to Murphy. However, the word don't like does not mean that Sophie hates Murphy but to show that Sophie is shy to admit that she likes Murphy.

These lines are the starting point where Sophie starts to like Murphy. She still feels confused of her feeling if she really likes Murphy or not. Sophie feels that she cannot feel in love with Murphy because he is not handsome. The function of these lines is to show her feeling that is still confused if she really loves Murphy or not.

These lines are related to the third theme because it proves that love is not determined by someone's physical appearance. As we know, Sophie is not attracted to Murphy because his uninteresting physical appearance. However, it can be seen later that finally Sophie loves Murphy, because even without charming appearance, Murphy can make Sophie feels happy.

\section{Hyperbole}

There are 133 lines of Hyperbole in the novel-in-verse that contributes to the three themes. These are two of the examples:

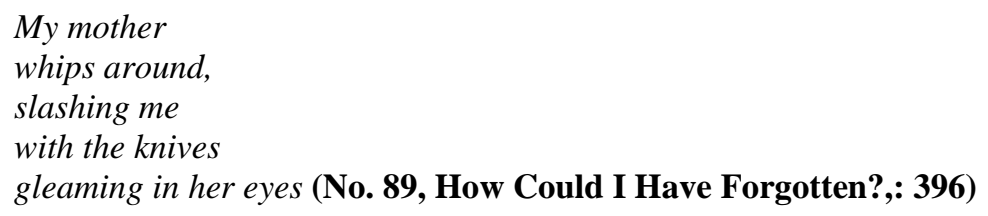


The main concern in these lines is the words slashing, gleaming and eyes. The verb slashing means to make a long cut with a sharp object and gleaming as a verb means to look very clean or bright. The author uses the word slashing to show someone's emotion / anger when he or she wants to cut someone with a sharp thing and gleaming means to express someone's seriousness. Meanwhile, the author uses eyes because eye can show emotion deeper than any other part of human body. So, the function of the author in using those words is to show to the readers the seriousness in Sophie's mother eyes because she is really angry with Sophie.

It is also used to show Sophie's anger to her mother. She shows her anger through a bad statement that she makes because her mother does not allow her to use another dress besides her mother's choice. From the above explanation, the lines are related to the second theme. The lines explain about Sophie's mother anger and Sophie's feeling of annoyance and anger to her mother.

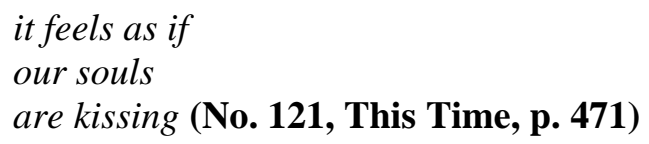

The main concern in these lines is the words souls and kissing. The noun means a person's inner character, containing their true thoughts and feeling and the verb means to touch somebody with your lips as a sign of love, affection, sexual desires, etc. The author uses the word souls as the noun with a purpose instead of using we to stress the all feelings that Sophie feels. The author wants to explain that Sophie feels Murphy's kisses with her heart and mind.

These lines are related to the third theme because it proves that love is not determined by someone's physical appearance. At first, Sophie is not attracted to Murphy because of his uninteresting physical appearance. However, from the lines it can be seen that finally Sophie loves Murphy, because even without charming appearance, Murphy can make Sophie feels happy.

\section{The relationship between the five figurative languages and the themes}

The total poems in the novel-in-verse What My Mother Doesn't Know are 195 poems and the totals of the poems that use the figurative languages are 139 poems or 71.28 percent. From those 139 poems, there are 127 poems or 91.36 percent are poems that related to the three themes and containing the five figurative languages. In the percentage calculation below, each figurative language will be counted, and the total of the poems of each type of the figurative language analyzed will be divided by 127 (poems containing the five figurative languages and related to the three themes).

Of the lines related to the first theme:

Simile: is found in 4 poems, make up for $3.14 \%$ of the 127 poems.

Metaphor: is found in 7 poems, make up for $8.89 \%$ of the 127 poems.

Personification: is found in 4 poems, make up for $3.14 \%$ of the 127 poems.

Paradox: is found in 0 poem, make up for $0 \%$ of the 127 poems.

Hyperbole: is found in 28 poems, make up for $22.04 \%$ of the 127 poems.

Of the lines related to the second theme:

Simile: is found in 5 poems, make up for $3.93 \%$ of the 127 poems.

Metaphor: is found in 5 poems, make up for $3.93 \%$ of the 127 poems.

Personification: is found in 3 poems, make up for $2.36 \%$ of the 127 poems.

Paradox: is found in 3 poems, make up for $2.36 \%$ of the 127 poems.

Hyperbole: is found in 10 poems, make up for $7.87 \%$ of the 127 poems. 
Of the lines related to the third theme:

Simile: is found in 6 poems, make up for $4.72 \%$ of the 127 poems.

Metaphor: is found in 9 poems, make up for $7.08 \%$ of the 127 poems.

Personification: is found in 5 poems, make up for $3.93 \%$ of the 127 poems.

Paradox: is found in 3 poems, make up for $2.36 \%$ of the 127 poems.

Hyperbole: is found in 35 poems, make up for $27.55 \%$ of the 127 poems.

\section{CONCLUSION}

In expressing the first theme, the author is using more hyperbole than simile, metaphor, personification, and paradox. Then, in expressing the second theme, the author is using more hyperbole than simile, metaphor, personification, and paradox. Next, in expressing the third theme, the author is using more hyperbole than simile, metaphor, personification, and paradox. From the above explanation, the dominant figurative language used by the author is hyperbole. The author uses more hyperbole because usually teenager likes to exaggerate their expression such as their love expression, happiness expression, sadness expression, and anger expression.

From all the analysis above, it can be concluded that 91.36 percent of all the poems use the five figurative languages and are related to the three themes. The percentages are as follows.

1. Poems with simile have the portion of $11.81 \%$ from 127poems.

2. Poems with metaphor have the portion of $16.53 \%$ from 127 poems.

3. Poems with personification have the portion of $9.44 \%$ from 127 poems.

4. Poems with paradox have the portion of $4.72 \%$ from 127 poems.

5. Poems with hyperbole have the portion of $57.48 \%$ from 127 poems.

There are 91.36 percent poems that use the five figurative languages and related to the three themes. The finding shows that themes can be revealed from the figurative languages and by using figurative languages; we can easily discover the style used by the author in expressing the teenagers feeling. 


\section{REFERENCES}

Arp, T. R. 1984. Perrine's Sound and Sense: An Introduction to Poetry. Orlando: Harcourt Brace \& Company.

Arp, T. R., \& Johnson, G. 1959. Perrine’s story and structure. Boston: Thomson Higher Education.

“All American: Glossary of Literary Terms”. Retrieved March 28, 2008, website: http://www.uncp.edu/home/canada/work/allam/general/glossary.htm

Barnet, S., Burto, W., \& Cain, E. W. 2005. Literature for Composition: Essays, Fiction, Poetry, and Drama. New York: Pearson Longman

Barry, P. 1995. Beginning Theory. Manchester: Manchester University Press

Bradford, R. 1997. Stylistics. London: Rout ledge.

Gill, R. 1995. Mastering English Literature. New York: Palgrave.

Kennedy, X. J. 1979. Literature: An Introduction to Fiction, Poetry, and Drama. Canada: Little, Brown \& Company.

Kennedy, X. J., \& Gioia, D. 2005. Literature: An Introduction to Fiction, Poetry, and Drama. New York: Pearson Longman

Leech, G. N. 1969. A Linguistic Guide to English Poetry. England: Pearson Education Limited.

Leech, G. N., \& Short, M. H. 1981. Style in Fiction: A Linguistic Introduction to English Fictional Prose. London and New York: Longman.

“Literary Terms”. Retrieved March 28, 2008 website: http://academic.brooklyn.cuny.edu/english/melani/lit_term.html

McArthur, T. 1992. The Oxford Companion to the English Language. Oxford: OUP.

Smith, V. “What Is Poetry?” Retrieved September 25, 2007, from Gallaudet University website: http://depts.gallaudet.edu/englishworks/literature/poetry.html\#basic

Talib, I. S. “A Brief List of Some Key Terms in Literature.” Retrieved March 17, 2008, from School zone website: http://courses.nus.edu.sg/COURSE/ELLIBST/lsl01-tm.html

Taylor, R. 1981. Understanding the Elements of Literature: It's Forms, Techniques and Cultural Conventions. New York: St. Martin’s Press, Inc.

Wales, K. 2001. A Dictionary of Stylistics. England: Harlow 